\title{
Affirming Genocide Knowledge through Rituals
}

Parts I and II of this book examined the emergence of repertoires of knowledge regarding the Armenian genocide through social interaction, objectified thought processes, bearing witness, and the involvement of knowledge entrepreneurs. We saw how knowledge generated through these processes took radically different shapes as it became sedimented within each of two distinct carrier groups, Armenians and Turks. Oppositional worldviews and associated knowledge repertoires are not unique to this case, of course. We find them, for example, when those who recognize the role of human action in global warming encounter others who see a Chinese conspiracy at work, aimed at harming the U.S. economy. Or again, when those who know that liberal or social democracy will secure a prosperous and secure future disagree with followers of populist authoritarian leaders and parties. The question arises of how each collectivity deals with the challenges posed by the other side.

Now, in part III, we encounter two strategies commonly deployed in struggles over knowledge. While chapters 7 and 8 address conflictual engagement with the opposing side in the realms of politics and law, and chapter 9 explores counterproductive effects of denial in an age of human rights hegemony, the present chapter examines the use of elaborate public rituals toward the reaffirmation of genocide knowledge within each of the contending collectivities.

We owe early social-scientific insights into the role of rituals in social life to Émile Durkheim. In his book The Elementary Forms of Religious Life, Durkheim ([1912] 2001) tells us about the ability of rituals to sanctify objects and charge symbols that represent them with a special energy. Rituals also generate collective effervescence-a sense of shared excitement and, in consequence, of groupness and belonging among those who partake in them. Durkheim's student Maurice Halbwachs (1992), who coined the term collective memory, applied these ideas to 
strategies through which actors achieve knowledge about past events. Contemporary sociologists recognize that rituals take place in all spheres of life, while that which they sanctify varies. The latter may include otherworldly entities in the sphere of religion; claims of truth in scholarship; justice in law; health in medicine; or the nation and its protection in the military.

\section{RITUALS AND THEIR CONSEQUENCES: A WEALTH OF RESEARCH AND CRITIQUES}

Some current scholarship provides clear, almost operational, conceptions of rituals and their consequences. Randall Collins (2005:48), for example, spells out these ingredients: "1. Two or more people are physically assembled in the same place, so that they affect each other by their bodily presence, whether it is in the foreground of their conscious attention or not. 2. There are boundaries to outsiders so that participants have a sense of who is taking part and who is excluded. 3. People focus their attention upon a common object or activity, and by communicating this focus to each other become mutually aware of each other's focus of attention. 4. They share a common mood or emotional experience." The copresence of these elements generates the collective effervescence and its consequences about which Durkheim wrote. We know manifold examples of such rituals from our own experience. Consider, in the secular realm, a graduation ceremony or Fourth of July celebration; or, in religious life, an Easter mass, a Friday prayer during Ramadan, or a Yom Kippur service.

Today, in our mass-mediated societies, physical copresence is still highly effective, but it may no longer be a necessary precondition for the mobilization of emotional energy. In fact, concrete embodied rituals themselves may become enduring symbols that carry the ritual charge through time. Filmed depictions of events are one mechanism (Dayan and Katz 1992), and the analysis below will reference both embodied rituals and their depictions in film.

Rituals work especially well when the symbols they sanctify align with some preexisting belief system. Alexander Riley (2008) provides a powerful illustration when he examines symbols used in the memorialization of victims of United Airlines flight 93. That flight-hijacked by a group of terrorists intending to destroy the U.S. Capitol Building or the White House-crashed in a field in rural Pennsylvania on September 11, 2001. Those who designed the memorial sought to celebrate the passengers as heroes, a first line of defense in the nation's new fight against international terrorism. They stacked the memorial with symbols that speak to larger themes in the nation's history and (closely allied) in Christianity. An initial, improvised memorial featured a forty-foot steel fence, one foot for each passenger killed; a cross, marking the area as sacred ground; and "angels of freedom," one for each passenger, who were thereby depicted as saintly figures. A "thunder flag" displayed four stars, each representing one site of destruction, and three bars: one blue, symbolizing the heavens; one white, representing the purity 
of the heroes; and one red for the earth of America. Constructed later as a place of commemoration, a "Thunder on the Mountain Chapel" featured an altar resembling the Capitol Building in Washington, D.C., and thus representing the nation, and an eagle as a symbol of deliverance, pointing upward.

A wealth of scholarship has built on Durkheimian thought about rituals and their effects on knowledge. Mary Douglas (1966) explored how rituals separate humans and their dignity from polluting matters-degrading substances, utterances, or actions. Edward Shils (1981) observed how civic rituals celebrate the sacred even in secular life; with Michael Young, he depicted the coronation of Queen Elizabeth II as a ritual that generated national communion within the United Kingdom, thereby supporting shared moral values (Shils and Young 1953). Robert Bellah (1970) relatedly wrote about civil religion-practices that connect the American nation with God and that sanctify persons, places, and events such as George Washington, Abraham Lincoln, John F. Kennedy, or Gettysburg. Through that sanctification, American civil religion provides the American people with a sense of meaning and direction.

Rituals are especially powerful in times of crisis, as Kai Erikson ([1966] 2004) showed in his famous study on punishment in the Massachusetts Bay Colony. Describing three "crime waves," Erikson demonstrates how during these periods, not actually marked by increased criminal behavior, people experienced a perceived threat to the unity of the colony. Perceptions of threat resulted from the arrival of new, less religiously dogmatic immigrants, a loss of political autonomy, and internal discord. They advanced three waves of ritual punishment, of which the Salem witch hunt is best known. Erikson interprets the outcome of these penal campaigns as the redrawing of boundaries around the community and the strengthening of its inner coherence and normative commitment. This benefit came at a price, however, that had to be paid dearly by those defined as responsible for social crises and insecurity.

\section{Rituals and Conflict}

Powerful as this body of Durkheimian scholarship is, it nevertheless faces criticism (Smith and Riley 2009). Many studies on rituals assume that consensus and social integration are the only outcome. That assumption, however, may not always hold true, and even when rituals achieve such outcomes, the mechanisms remain obscure. Critics further charge that work in the Durkheimian tradition is idealistic, that it fails to recognize agency, intent, conflict, force, and power (e.g., Goody 1977; Lukes 1975; Turner 1969).

Scholars have argued, and the following will prove them right, that we can take these criticisms seriously and still hold on to the insights a theory of ritual has to offer us. In fact, the explanatory power of Durkheimian theories increases if we incorporate the possibility of discord and the role of power and authority. Yes, rituals may indeed produce consensus, but they may also generate conflict. At times, conflict intensifies exactly as a result of the integrative force of rituals, which 
is easy to see where intergroup conflict is concerned. By strengthening a sense of belonging and shared ideas within one group, say Turks or Armenians, rituals draw the boundaries to the outside group ever more starkly (see also Simmel [1955] 1964; Coser 1956). Consequently, intergroup conflict is likely to intensify.

Rituals may even generate conflict within a collectivity. Consider a group of Turkish intellectuals gathering for a set of lectures and symposia that seek to challenge the dominant Turkish discourse on the violence of 1915. Exactly this happened in the early 2000s, when a network of journalists and scholars, including many Turks, created a "Workshop for Armenian Turkish Scholarship." A March 2000 conference at the University of Chicago was followed by others in Michigan (2002), Minnesota (2003), Salzburg (2005), New York (2006), and Geneva (2008) (Bayraktar 2010:185-186). These gatherings, conceived of as scholarly rituals, helped sanctify a truth claim about the Armenian genocide that generated conflict within the Turkish context while generating collective effervescence and intensified relationships among participating scholars. Through the latter, it laid the foundation for future scholarship in opposition to dominant Turkish repertoires of knowledge.

We gain further explanatory power, linking back to Randall Collins's ingredients of rituals, when we ask who has the resources, power, and influence to bring together many human beings in one place. Who draws boundaries to the outside world, deciding who partakes in the ritual and its products and who is excluded? Or: Who is capable of transmitting rituals to a broader public via modern media of communication? Further, given the variable content of rituals, who determines which actors say and do what during the ritual, and what objects are offered for sanctification? Finally, what motivates those organizers of rituals, and what power potential or other tools help them achieve their goals?

\section{Rituals, Interests, and Power}

Actors, their motivations, and the tools they use to initiate and structure rituals are crucial for their courses and consequences. Consider struggles over the initiation and content of rituals that explicitly aim at the construction and preservation of specific collective memories. Alejandro Baer (2011) describes how Spain, during the Franco regime, repressed engagement with Holocaust history, not surprising in light of the Hitler-Franco alliance dating back to the Spanish Civil War. Spain began to engage with these dark chapters of history only after the transition to democracy of the 1970s. This engagement eventually culminated in the country joining the Stockholm International Forum on the Holocaust (2000), initiated by the Swedish government and seeking to secure the memory of genocides.

In Spain, democratization thus provided Jewish organizations with new opportunities. They successfully suggested an official commemoration, and an initial commemorative ceremony took place on May 3, 2000, in the Madrid Assembly, the seat of the regional government. The ceremony culminated in the lighting of 
six candles, echoing a practice from Yad Vashem, Israel's official Holocaust memorial center, each candle representing one million of the six million Jewish victims of the Shoah. The election of a socialist government in 2004 opened further opportunities, resulting in the first ceremony officially sponsored by the national government in Madrid. Yet the proposed structure of the ritual provoked conflict. The organizers invited representatives of other victim groups to participate, but only in the candle lighting ceremony; they were not invited to deliver speeches. Republican associations, representing those who had fought the Franco regime in the Spanish Civil War, protested. When the organizers eventually included one of their representatives, Enric Marco, presumably a former inmate of the Mauthausen concentration camp, in the list of speakers, new conflict erupted. Marco referenced Guantanamo Bay and "camps in Palestine," generating intense resentment among Jewish attendees. In response, later ceremonies went through a series of modifications, each of which resulted in new struggles (Baer 2011).

The example of Holocaust commemorations in Spain illustrates how conflict, interest, and power accompany the introduction and structuration of commemorative rituals. Each year's event reflects a new political situation resulting in the incorporation of new memories, in line with Halbwachs's (1992) argument about presentism of memory. Yet we cannot understand these commemorations without considering the previous years' events and the sensitivities they evoked. Memory is thus also path dependent, in line with arguments Jeffrey Olick developed when analyzing series of contested German May 8 commemorations of capitulation at the end of World War II (Olick 1999, 2016). Each of these commemorations gravitated between the notions of Germany's liberation versus its defeat, with their respective sensitivities. The story of Holocaust commemorations in Spain also confirms insights by Francesca Polletta (1998), who examined how interactions between power holders and challengers result in shifting modes of public commemoration and protest repertoires, including the creation of new holidays. ${ }^{1}$

In short, rituals play an important role in social life. They are suited to sanctifying moral standards and sets of knowledge, including memories of difficult pasts. They are typically initiated and structured by powerful and motivated actors, representatives of collectivities, with the intent to generate solidarity and a shared perception of reality. What role, then, do rituals play in solidifying knowledge about the mass violence of 1915 and subsequent years in Armenian life, and in Turkish life, when each group faces challenges from the other side?

\section{ARMENIAN RITUALS AND THE SOLIDIFICATION OF ARMENIAN KNOWLEDGE REPERTOIRES}

The Tsitsernakaberd Memorial Complex, high on a hill overlooking Armenia's capital city of Yerevan, consists of three main buildings: the Memorial Wall, the Sanctuary of Eternity (Memorial Hall and Eternal Flame), and the Memorial 
Column, entitled "The Reborn Armenia" (see chapter 4). As a memorial made of stone, it represents collective memory. The description on the memorial's website testifies to the meaning inscribed in the hard stone with its seemingly eternal message. Yet that text itself was written in a particular historical situation, and current uses of the memorial continue to express the meaning Armenians bestow on it, especially on special ritual occasions such as the April 24 Armenian Genocide Commemoration Days. The following sections examine three events that took place in Yerevan on April 23 and 24, 2016, one of them at the memorial itself. Based on documents and participant observation, I interpret these events as rituals, and I consider their consequences for the reaffirmation and shape of repertoires of genocide knowledge.

\section{The Commemorative Ritual at Tsitsernakaberd}

On April 24, 2016, an early-morning bus took a group of international visitors, including this author, to the memorial. Along the way, the bus passed a steady procession of people who walked up the hill to lay down carnations in a circle around the eternal flame that burns at the center of the "Sanctuary of Eternity." ${ }^{2}$ Up on the hill, these visitors joined a crowd of foreign dignitaries, ambassadors, foreign ministers and representatives of various legislatures from around the world, who were gathering at the end of the Memorial Wall. It was a beautiful spring day. The sun was intense. Looking south, our eyes met snow-capped Mount Ararat and its smaller twin peak, sacred to the Armenians but just across the border in neighboring Turkey. Mount Aragats towered in the north. When Armenia's president, Serzh Sargsyan, arrived, he was accompanied by his cabinet, the Catholicos of the Armenian Church, and several guests of honor, including prominent members of the Armenian expatriate community, survivors of the genocides in Cambodia and Rwanda, and celebrities such as actor and activist George Clooney. Slowly the crowd moved along the Memorial Wall, toward the Memorial Hall with the Eternal Flame. The procession came to a halt when the dignitaries had reached the end of the wall closest to the hall. Prayers were said, a choir sang religious and patriotic songs, and military honors were performed. President Sargsyan laid down a wreath, and then, followed by the crowd, slowly descended the steps into the memorial. The carnations that the president, the guests of honor, and members of international delegations laid down in a circle around the flame added to an already meter-high wall of flowers deposited by those who had moved in procession up the hill earlier in the day (see figure 5). When returning to the hill in the late afternoon, a similarly dense procession of Armenians still made its way up the hill, commemorating the genocide and paying respect to those whose lives had been destroyed.

The April 24 event at the Tsitsernakaberd Memorial Complex certainly fulfills the criteria of a ritual. Many people were physically assembled; the Memorial Wall and other architectural elements constituted boundaries to outsiders; 


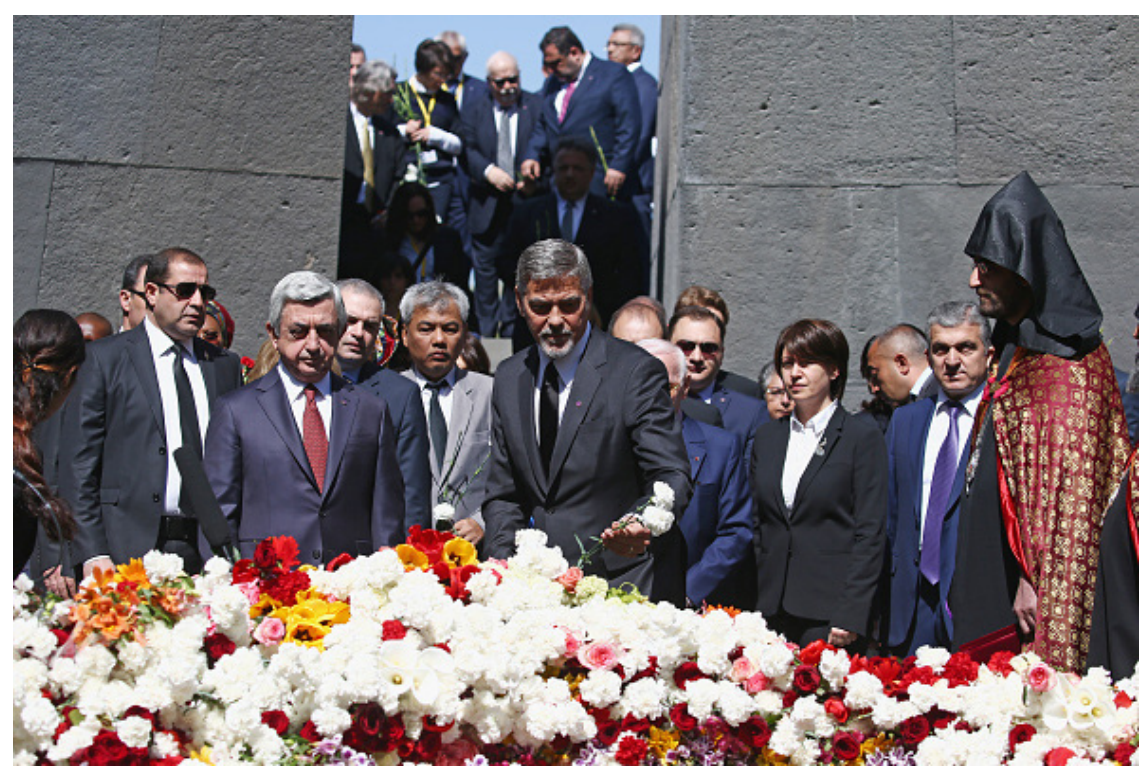

FIGURE 5. A procession bearing flowers descends into the Memorial Hall, where the Eternal Flame is located, at Tsitsernakaberd Memorial Complex, Yerevan. Photo by Andreas Rentz/ Getty Images for 100 Lives.

people directed their attention to a common object or activity, and became mutually aware of each other's focus of attention; they finally shared a common somber mood. Those in attendance were reminded of the history of the genocide and its centrality to the identity of the Armenian people. They experienced a sense of collective effervescence, a sentiment of solidarity, of the sacredness of the place and the occasion.

The structure of the event and the identity of those who participated carefully displayed several messages. The presence of the country's president and the Catholicos; their words, prayers, and rites; and the combination of religious and patriotic songs demonstrated the intimate relationship between the state and the Armenian Church. Participation by ambassadors and other representatives of many governments around the globe reflected the growing international recognition of the genocide and solidarity with the Armenian people. Finally, the presence of survivors of other, more recent genocides, globally defined as such, supported the labeling of the violence of 1915 as a genocide, while simultaneously expressing Armenian solidarity with other victimized peoples.

Central organs of the Armenian state and church organized the event, determining the initiation and structuration of this ritual. The power and authority of these entrepreneurs of knowledge and memory were crucial. Simultaneously, however, the mass procession up the hill by tens of thousands of ordinary 
Armenians attested to the shared memory, the result of manifold day-to-day interactions, of the telling of stories across generations. Documents indicate that the commemorative event of 2015 , on the one hundredth anniversary of the genocide, was organized similarly, even if the presence of several heads of state, including the presidents of Russia and France, underlined the special significance of the centennial (Mkrtchyan 2015).

As powerful as the ritual at Tsitsernakaberd was in its own right, we will understand its meaning better if we consider it in context. Sociologist Theodore Caplow (2004) used the term festival cycle, exploring how the meaning of a holiday reveals itself most powerfully when we see it in the context of other holidays. In this spirit, I examine two other events that surrounded the commemorative ritual at Tsitsernakaberd. The first, a Global Forum Against the Crime of Genocide, was held on the day preceding the memorial ceremony. The final event, concluding the cycle, was an award ceremony on the evening of the day of commemoration, several hours after the ritual at the memorial. It celebrated the newly created Aurora Prize for Awakening Humanity. Both events took place in Yerevan's massive sports and convention center, sited on the same hill as the genocide memorial.

\section{Global Forum Against the Crime of Genocide}

On Saturday, April 23, 2016, a Global Forum Against the Crime of Genocide was held, organized by the Ministry of Foreign Affairs and the National Assembly of the Republic of Armenia. Also involved was a "State Committee for Coordination of the Events Dedicated to the Centennial of the Armenian Genocide." The organizers titled the forum "Living Witnesses of Genocide." The event took place in a large hall in front of an audience of some eight hundred participants, including diplomats and other representatives of foreign governments, members of the Armenian legislature, a small group of survivors of genocides, and scholars. An image of Mount Ararat provided the backdrop behind the speakers (see figure 6).

The Foreign Ministry's concept note describes the meaning of the event:

During the Global Forum 2016, entitled "Living Witnesses of Genocide", leading politicians, parliamentarians, scholars, media, civil society representatives, and other stakeholders from around the world will address genocide-caused refugee crises, ramifications of protection mechanisms, and, in general, genocide consequences.

The Forum will focus on the protection of people who became refugees because of genocide or its threat. The purpose of genocide perpetrators is to annihilate the representatives and culture of the targeted ethnic group, and as long as they succeed, it is impossible to break the vicious circle of genocidal acts.

For that very reason, the international community should be able to save lives of people subjected to genocide, their property, cultural and public institutions, create favorable conditions for their return, and provide rapid compensation for the destruction through international mechanisms of accountability. 


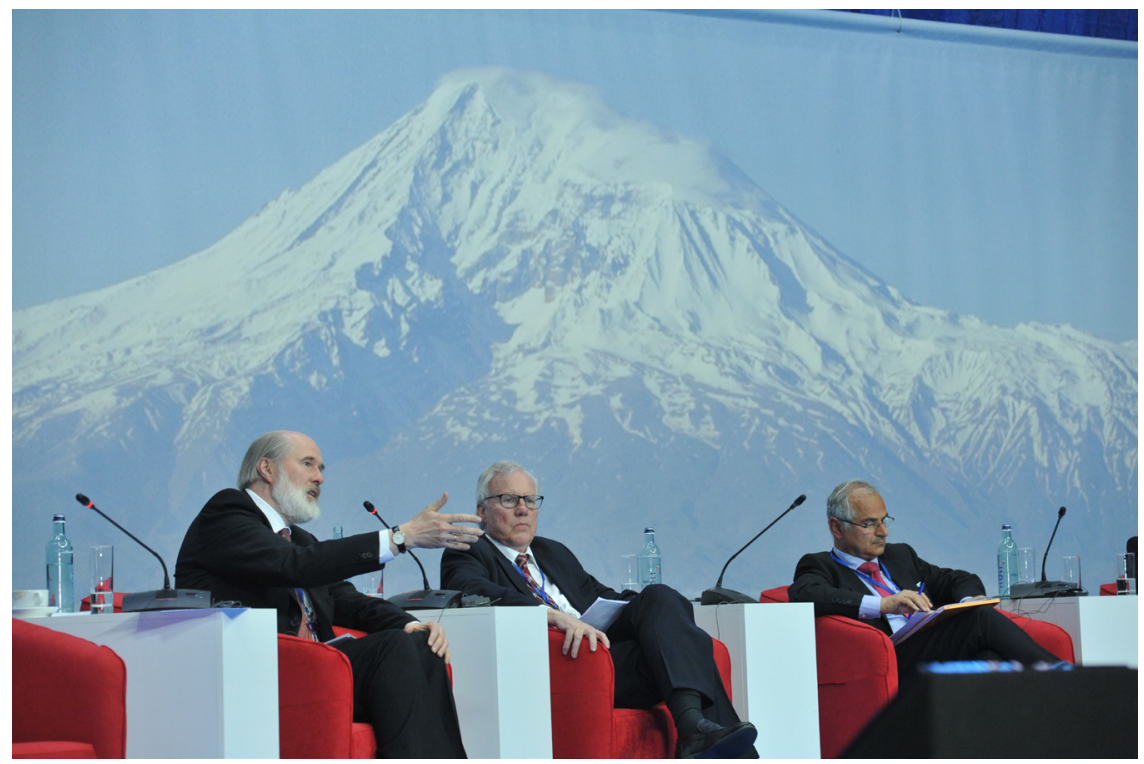

FIGURE 6. Discussion after a panel at the Global Forum Against the Crime of Genocide, Yerevan, 2016, with an image of Mount Ararat as backdrop. Photo courtesy of Ministry of Foreign Affairs, Republic of Armenia.

By organizing the forum in this universalistic spirit, the government of Armenia not only expresses solidarity with other victims of genocide. In addition-and in combination with the commemorative event of the following day ("festival cycle," à la Caplow) - it also pleads for the saving of lives "of people subjected to genocide, their property, cultural and public institutions." It demands that the international community create "favorable conditions for their return, and provide rapid compensation for the destruction through international mechanisms of accountability." The last set of demands is still applicable, in principle, to the violence experienced by the Armenian people, even if the text does not make that explicit.

We gain more insights by examining specifics of the unfolding forum. The event was opened at 10 a.m. with a speech by President Sargsyan, followed by a "Highlevel Dialogue" moderated by David Ignatius, a self-identified Armenian American and a columnist and associate editor for the Washington Post. This dialogue included statements by President Sargsyan; Andrew Woolford, president of the International Association of Genocide Scholars; George Clooney, UN peace envoy and cofounder of Not On Our Watch, a nonprofit organization; ${ }^{3}$ Joe Verhoeven, judge ad hoc of the International Court of Justice; and Vartan Gregorian, president of the Carnegie Corporation of New York. Clearly, such a panel demonstrates the country's ability to align behind its agenda diverse sectors of international law, scholarship, and civil society. 
The Ministry of Foreign Affairs' concept paper entitles the subsequent Panel Number 1 "Genocide and Displacement: Identifying Genocide from the Perspective of Forced Displacements and Relocation." It describes the panel's charge: "Genocide is an extreme form of identity-based violence. . . . This Panel will concentrate on different stages of genocide in the context of displacement by trying to address the following issues: The common patterns of displacement and relocation in the planning and perpetrating [of] genocide. Displacement as an indicator of the intent to destroy particular groups in part or in its [sic] entirety."

Presenters included professors of international law, philosophy, history, and Jewish studies; a scholar in Russian and Eurasian studies; and human rights activists from a variety of countries, including Germany, the United Kingdom, the United States, Switzerland, and Turkey. Support for the notion of justice against perpetrators of mass atrocities was a common denominator of the presentations. Panel 2, entitled "Preventing Genocide and Protecting Refugees: Contemporary Challenges," featured a sociologist, an anthropologist, a historian, and international lawyers from Italy, the United States, and Sweden. It concluded with a speech by Hayk Demoyan, director of the Armenian Genocide Museum-Institute.

Bringing together an international and interdisciplinary group of scholars in Yerevan to elaborate on issues of genocide on the day before the official Armenian genocide commemoration, the global forum added legitimacy to the identification as genocide of the mass violence against Armenians during World War I. Indirectly, it validated moral and legal claims that today are associated with the notion of genocide.

Artak Zakaryan, chairman of the Standing Committee on Foreign Relations of the National Assembly of the Republic of Armenia, and Garen Nazarian, deputy minister of foreign affairs of the Republic of Armenia, cochaired the closing session. It included presentations by the Speaker of the National Assembly of the Republic of Armenia, and testimonies of genocide survivors. Addresses by guests and delegates followed, mostly ambassadors and representatives of legislatures or administrations of numerous countries. The final speaker was Edward Nalbandian, minister of foreign affairs of the Republic of Armenia, who bridged events and speeches of the day to Armenian claims in the conflict with Azerbaijan over the Nagorno-Karabakh region. In this most political of all the panels, the foreign minister significantly attached contemporary foreign policy claims to an event that had addressed consequences of genocide, on the night preceding the Armenian genocide commemoration. Unsurprisingly, a commemoration organized by a foreign ministry does not unfold in neutral political space. Memory and politics in such settings are intertwined.

In short, we can conceive of the Global Forum Against the Crime of Genocide as a ritual, marked by physical copresence, boundaries to the outside, a shared focus of attention, mutual awareness, and a common mood. It generated an understanding of genocide and its horrors, agreement on the inappropriateness of impunity 


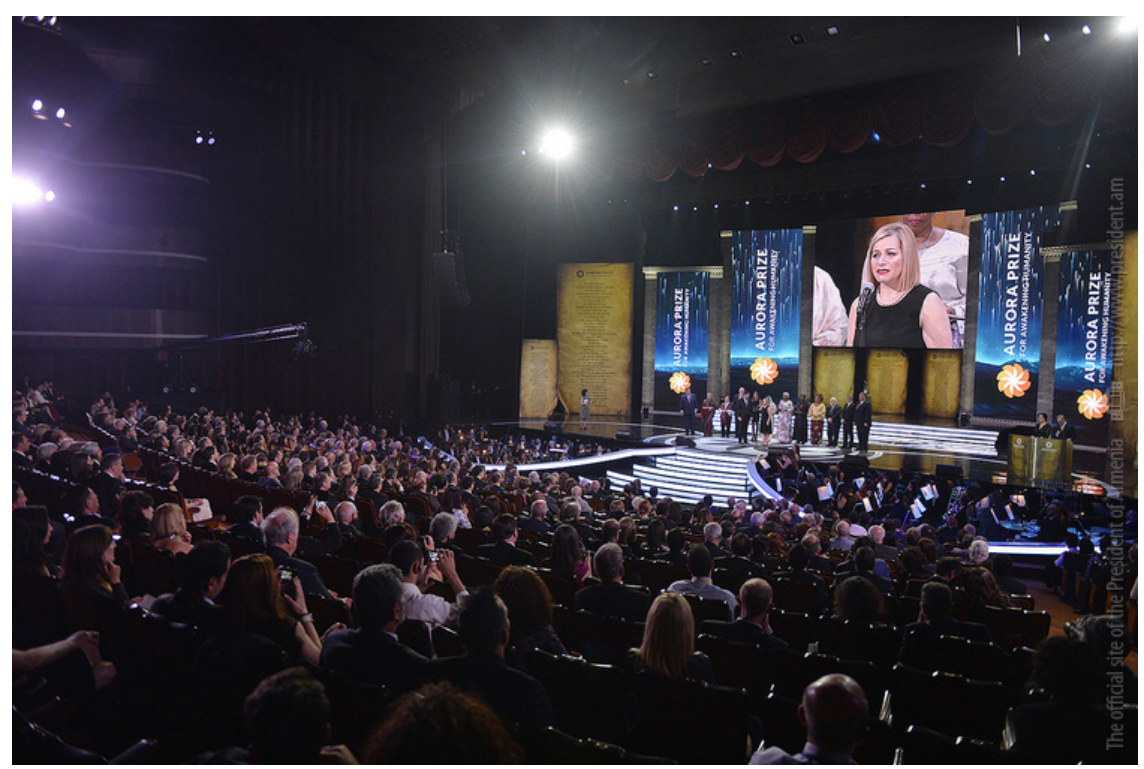

FIGURE 7. Aurora Prize Ceremony, Yerevan, 2016. Photo courtesy of Ministry of Foreign Affairs, Republic of Armenia.

for those who initiate, execute, or sanction genocide, and an identification with knowledge, ideas, and symbols that the proceedings had sanctified. The inclusion of genocide scholars from various disciplines and countries added legitimacy for the use of the genocide label and associated claims. Finally, the inclusion of survivors of recognized genocides reaffirmed the validity of the categorization of the mass violence against the Armenians during World War I as genocide.

The event allowed for an expression of solidarity and explicit acknowledgment, for which the ritual at the memorial at Tsitsernakaberd could not provide space. In preceding the commemorative rite, the forum's statements carried over into the gathering at the memorial on the following morning. Adding cognitive content to the affectively charged ritual at the memorial, it reaffirmed basic elements of repertoires of knowledge about the Armenian genocide.

\section{Aurora Prize Ceremony: Dance, Stories, and the Power of Oneness in Ritual Performance}

A third event completed the cycle of rituals held in Yerevan in 2016. On the evening of Sunday, April 24, following the morning's wreath laying ceremony at the Armenian Genocide Memorial, a profoundly moving event took place in a large theater that is part of the sports and convention complex on the hill overlooking Yerevan. The occasion was the first Aurora Prize Ceremony (figure 7). An estimated two thousand people attended. The organizers' concept note describes the prize and the event: 
The Aurora Prize for Awakening Humanity is a new global award that will be given annually to people who put themselves at risk to enable others to survive. Recipients will be recognized for the exceptional impact their actions have made on preserving human life and advancing humanitarian causes, having overcome significant challenges along the way. Every year the winners will be honored with a \$100,000 award as well as the unique ability to continue the cycle of giving by nominating an organization, which inspired their work and is consistent with the spirit of the Prize, for a $\$ 1,000,000$ grant. The Aurora Prize is designed to further the causes that motivate people to risk their health, freedom, reputation or livelihood by voluntarily carrying out acts that enable others to survive and thrive.

The program note then lists the members of the Aurora Prize Selection Committee as follows:

- George Clooney, Co-founder, Not On Our Watch, humanitarian, performer and filmmaker;

- Elie Wiesel, President of the Elie Wiesel Foundation for Humanity, Nobel Laureate;

- Hina Jilani, Former UN Special Representative of the Secretary-General on Human Rights Defenders;

- Vartan Gregorian, Co-Founder, 100 LIVES, President of the Carnegie Corporation of New York;

- Gareth Evans, Former President Emeritus of the International Crisis Group, Former Australian Foreign Minister;

- Mary Robinson, Former UN High Commissioner for Human Rights; Former President of Ireland;

- Óscar Arias, Two-time President of Costa Rica, Nobel Laureate;

- Shirin Ebadi, Human Rights Lawyer and Iran's first female judge, Nobel Laureate;

- Leymah Gbowee, Executive Director of the Women, Peace and Security Network (WIPSEN-Africa), Nobel Laureate.

The committee thus included four Nobel laureates and others in high positions in international non-governmental organizations and other international organizations. Participation by these persons displays solidarity with the Armenian people and its history of suffering, indirectly and directly confirming knowledge claims regarding the Armenian genocide.

As the event unfolded, capping the cycle of April 2016 commemorations, it displayed all the features of a ritual and conveyed a clear message about the Armenian genocide. I rely on a video recording ${ }^{4}$ and on my own observations and detailed note taking at and around the event in the Yerevan convention center.

The award ceremony opened with a five-minute animated film by Armenian filmmaker Eric Nazarian, a true masterpiece in condensation of national memory. The film shows a crane, flying over vast areas of land, imposing mountains, 
rolling green hills, towns, and churches. The narrator tells about an "ancient civilization" underneath the bird's wing, the "Land of Noah," about its millennia of building and survival, and its inhabitants' contribution to humankind. He tells of the "1.5 million who perished in 1915 together with their culture" and reaffirms Armenian genocide knowledge: "This was a genocide, perpetrated by the Ottoman Empire against its own citizens."

The voice further tells about the many refugees, including seventeen-year-old Aurora Mardiganian, the star of Ravaged Armenia, the first Hollywood film about the genocide. This silent movie was made in 1919, based on Aurora's 1918 autobiography. We learn that the film was, at the time, premiered and viewed by large audiences all over the United States, the United Kingdom, France, and Australia, and that the book sold one hundred thousand copies. Interspersed throughout the animated film is footage from Ravaged Armenia, including gruesome but fictional images of crucified young women. Historical photographs show death marches and survivors of the mass killings. The voice continues: "To this day, Aurora remains a testament to the living memory of the genocide and the gratitude of the Armenian people to their saviors. Aurora became a symbol of light and hope to an entire generation."

Approaching the conclusion of the film, the message shifts from despair to hope. The voice tells us about survivors in countries around the world. Images show the Statue of Liberty in New York and the Eiffel Tower in Paris, symbols of the two countries in which most Armenian refugees found a new home. The narrator speaks about refugees rebuilding their lives, with dignity, "ever grateful to those who rescued their families," who "put their own lives at risk to save survivors." Concluding images shift to present-day refugees, linking the film with the central theme of the 2016 global forum. The voice speaks about victims of today's man-made disasters. A globe appears on the screen, and the narrator summarizes the central message: "On behalf of the survivors of the Armenian genocide and in gratitude to their saviors, the Aurora Prize for Awakening Humanity honors the power of the human spirit that compels action in the face of adversity." The screen shows faces from around the world, and, finally, again, that of Aurora Mardiganian.

The film clearly connects the Aurora Prize Ceremony to the preceding two events, completing the cycle of commemoration. It reinforces the labeling of the mass violence against Armenians as a genocide and the count of those killed as 1.5 million. The film further pleads for solidarity with other peoples who suffered from mass violence and expresses gratitude and appreciation of those who aided survivors. Mindful of the power of oneness (Schwartz 2009), and in line with the title the founders had selected for the prize, the filmmaker introduces Aurora as a representative of the survivors of the Armenian genocide and of the survivors of mass atrocities generally.

A ballet, danced to music performed by the State Youth Orchestra of Armenia, is the second item on the evening program. Ten dancers of Foundation Ballet 2021 
appear on the mist-covered stage, in front of four saintly figures woven into a large curtain behind the stage. The dancers' movements are abrupt, signifying struggle, but the scene changes when the mist disappears and a single dancer enters the stage from the left, holding high a bronze sculpture, made up of three branches growing out of a common root. Each branch shows varying numbers of human figures, vertically on top of each other, rising upward, as though they are moving out of ashes into a new life. The sculpture, entitled To the Eternity, is a creation of the Armenian artist Manvel Matevosyan and was a prizewinner of a 2015 anniversary contest, “A Message 100 Years Later." A postcard with its image describes it as "12 figures symbolizing Western Armenia going up, to the eternity and the idea of canonization of the Great Genocide victims." The dancer carries the statue to the center of the stage and the curtain in the back of the stage rises, opening the view to a pedestal. The dancer places the statue on top of the pedestal and then raises his arms, like a priest sanctifying a sacred object. The other dancers, no longer in wild motion, stand still symmetrically to both sides of the sanctified sculpture. Exiting from the stage, they leave behind the emblem that from here on represents the Aurora Prize for the Awakening of Humanity. In future years, copies of the statue will be handed to the finalists and recipient of the Aurora Prize.

Following this ritual sanctification of the new emblem, introductory comments by two masters of ceremonies (MCs) ${ }^{5}$ reinforce the messages of the film and of the dance performance. They highlight that the inauguration ceremony takes place on Armenian soil on the anniversary of the "genocide" that took the lives of "1.5 million people." They introduce separate awards ${ }^{6}$ preceding the core of the event. Eventually, the awarding of the Aurora Prize unfolds in four types of delicately interwoven segments: musical performances, parables told by the MCs, video messages from absent members of the award committee, and the introduction of the Aurora Prize finalists by members of the committee. It culminates in the announcement of the recipient. A few words on each element shed further light on the emotions evoked and the knowledge confirmed through the ritual of the award ceremony.

Auschwitz survivor and Nobel laureate Elie Wiesel speaks-via video, accompanied by pictures of 1915-to the importance of solidarity in the face of atrocity. His appearance establishes a link between the Holocaust and the Armenian genocide, a particular form of analogical bridging. Other video messages come from Mary Robinson, former Irish prime minister and UN high commissioner for human rights, and from Óscar Arias, former president of Costa Rica, who received the Nobel Peace Prize in 1987 for his efforts to end the bloody civil wars of Central America. Again, the structure of the ceremony embeds the history of the Armenian genocide within the worldwide struggle for human rights, and links it to other episodes of mass violence.

Three parables told by the MCs all entail the same message: that giving and supporting those in need is the greatest gain humans can attain, possibly a 
condition for their own survival. One example must suffice, told by David Ignatius: God shows the questioner two images of people sitting in front of delicious food, holding spoons attached to long handles. Those in one picture, depicting Hell, look emaciated, desperate; those in the other, showing Heaven, appear content, in fact happy. The questioner initially does not understand until he sees that those in Heaven use their spoons successfully by feeding each other. Those in Hell attempt to feed only themselves, but the long handle does not allow them to reach their mouths. The moral is in line with the spirit of the Aurora Prize, given to those who do extraordinary things to save others. In a Durkheimian move, the MCs juxtapose universal solidarity (the sacred) with individual-orientation and selfishness (the profane), confirming the epistemic power of narrative facility (Rydgren 2007).

The stage is thus set for the climax of the ceremony. Award cofounder Vartan Gregorian of the Carnegie Foundation and Liberian peace activist and Nobel laureate Leymah Gbowee tell the audience about the 186 nominees from twenty-seven countries, the selection committee, and its procedures. They and other committee members introduce the finalists, each introduction accompanied by an emotional video depicting their projects. ${ }^{7}$ Eventually, Marguerite Barankitse, founder of the Maison Shalom in Burundi, is announced as the award recipient; her actions "saved the lives of 30,000 Rwandan children" who had lost their parents during the genocide in neighboring Rwanda.

Orchestral music intensifies the emotionality of the event. Pieces include the finale of (Soviet-) Armenian composer Aram Khachaturian's Symphony of Bells; a famous Armenian lullaby, sung by Hasmik Papian, the co-MC; and a hymn to Armenia for orchestra and choir, performed in the presence of its composer, the French-Armenian chansonnier Charles Aznavour (born Shahnour Vaghinag Aznavourian). At the end of the ceremony, which has lasted for two hours and twenty minutes, the audience is released with images of Armenia and the appeal to shake off victimization and embrace a shared humanity.

Multiple conversations in the lobby immediately following the award ceremony confirmed its emotional impact. Collective effervescence was the outcome of a ritual that had brought many people together, attentive to the same unfolding events on the stage of the hall, aware of each other's focus of attention, and sharing a common mood. Intense emotions supported the cognitive message.

What Theodore Caplow called the festival cycle had thus concluded. A conference, a ceremony at the genocide memorial, and an award ceremony mutually reinforced and supplemented each other's messages. They instilled and reinforced knowledge the event had repeatedly communicated to the audiences: that the 1915 violence against the Armenians, committed by the Ottoman Empire, indeed constitutes a genocide; that 1.5 million Armenians lost their lives; that the suffering of Armenians links them to victims of other genocides; that all of these groups share a sense of solidarity; that liberators from suffering are to be celebrated as heroes; and that victimized peoples must overcome their victim identity, as helpers and 
practitioners of solidarity with others who suffer today. Durkheimian ideas about the emotional and cognitive power of rituals find support. Viewers of the videorecorded award ceremony will share some of the experience that moved those who were physically present.

Local rituals supplement grand national events. In Yerevan, they include a reading of "unanswered letters" from the time of the genocide in the Armenian Museum of Arts and Literature ${ }^{8}$ and a celebration of commemorative art. ${ }^{9}$ In the diaspora, communities around the globe organize commemorations. In 2015, for example, on the centennial of the genocide, Minnesotans held a memorial service in the Armenian Saint Sahag Church, welcoming, under the guidance of its pastor Tadeos Barseghyan, speakers such as U.S. Senator Amy Klobuchar, members of the U.S. House of Representatives, and members of the state legislature. Academic events at the University of Minnesota supplemented commemorations. ${ }^{10}$

In short, in Armenia's capital city of Yerevan and in the diaspora, April 24, the day of commemoration of the Armenian genocide, provides an opportunity for powerful rituals. These rituals evoke emotions and simultaneously acknowledge and reinforce Armenian knowledge repertoires. They strengthen Armenian communities and identity, and they spread the message to broader audiences around the globe.

\section{TURKISH RITUALS AND THE SOLIDIFICATION OF TURKISH KNOWLEDGE REPERTOIRES}

Rituals can acknowledge evil and suffering, but by selectively highlighting the glorious history of a collectivity, they can also contribute to denial of evil, to the drowning out of utterances that risk polluting both the sanctified past and a current-day identity built on that past (Vinitzky-Seroussi and Teeger 2010). This indeed is the situation of Turkey.

\section{Celebratory and Purifying Rituals: Reaffirming the Ottoman Past}

It is again a young Turkish scholar, sociologist Yağmur Karakaya, who-joining the likes of Taner Akçam, Seyhan Bayraktar, and Fatma Müge Göçek-reflects critically on Turkish practices. In recent work, Karakaya (2018) analyzed a ritual in Istanbul that commemorates the conquest of Constantinople on May 29, 1453, under the command of Ottoman Sultan Mehmed II (also known as Fatih), and with it the final defeat of the Eastern Roman Empire.

Organized by the AKP, the Justice and Development Party headed by President Recep Tayyip Erdoğan, the event cultivates nostalgia for Ottoman Islamic civilization as a source of Turkish heritage. Note that this same civilization also brought the near destruction of the Armenian people and great suffering to Ottoman Greeks, Assyrians, and other minorities. Not accidentally, such nostalgiaconnecting a people with an imagined past, creating a sense of collective identity and a wholesome future-coincides with a period of authoritarian populist politics. 
In 2016, the same year in which the Armenian events in Yerevan described above took place, one to two millions Turks gathered in Istanbul, and tens of millions across the country joined the nationally televised ritual in front of TV screens. Karakaya describes the event as a "massive rally-one of many throughout the year-[which] combined the latest technology, such as laser light shows and high volume bombastic music through loudspeakers, with Ottoman elements, such as the military marching band [563 strong, equaling the number of years since the conquest], marching to beats that had long ago inspired the Ottoman troops, and virtual neighing and galloping horses, to create a carnivalesque political scene" (Karakaya 2018:126).

Karakaya observes how, in line with the myth of Fatih entering into Istanbul riding a white horse, Erdoğan arrived on the rally ground in a white helicopter. The "announcer declared his arrival like a town crier ... Istanbul! Here comes the protector of the oppressed, hope of the poor, the strong voice of the underdogs, child of the nation, here comes the fearless advocate of the just cause, grandson of Fatih, apple of the ummah's eye, architect of new Turkey, servant of the nation, president of the republic!" (Karakaya 2018:135). In his speech, Erdoğan referred to the crowd as "the grandchildren of Mehmed the Conqueror" (Karakaya 2018:135). He posed a series of rhetorical questions, each asking for a milestone of economic or development success, and the crowd, in unison, answered "Yes!" Erdoğan appealed to the ummah, solidarity with-and Turkish leadership of-the Muslim world. Appearing as a messianic figure, Erdoğan in fact mobilized religious sentiments.

Binaries abounded. The world is one of "winners and losers, oppressors and the oppressed, West vs. East, friends vs. enemies, us vs. them, strong vs. weak, and the dog-whistle Islam vs. Christianity" (Karakaya 2018:137), and the assembled crowd repeated after its leader: "One nation, one flag, one fatherland, one state" (Karakaya 2018:139). The organizers of the ritual further intensified collective effervescence through the event's mise-en-scène, incorporating uplifting music, famous actors from a state-sponsored Ottoman-themed film series reading emotion-laden poems, and jet planes roaring over the crowd. Visual effects, produced by a high-tech light show, repeatedly simulated the breach of the city's fortifications in 1453. Clearly, physical copresence, a shared focus of attention, a shared mood, and mutual awareness provided the event with the quality of a ritual. In addition, and in line with Dayan and Katz's (1992) arguments, the millions watching in front of their television screens, far away from Istanbul, also tanked up on emotional energy.

Emotions (to contradict a widely held belief) do not exclude cognition and knowledge. Karakaya observes correctly how participants feel a need to attribute meaning to their emotional state, in the form of knowledge about the greatness of the nation and the wickedness of its enemies. Repudiating Mustafa Kemal Atatürk and his model for the secular Turkish Republic he founded in 1923, the new script favors a glorious image of Ottoman history. The collective memory associated with this image, the knowledge repertoire it fosters, excludes dark chapters of Ottoman 
history, including knowledge of genocide committed in the name of the nation. Even if Karakaya's interviewees from different parts of Turkey do not wholeheartedly support the spectacle of the Conquest ritual, all believe in the sanctity of the Ottoman past.

Karakaya's analysis supports arguments about the epistemic power of memory entrepreneurs. They initiated and structured the elements of the Conquest ritual, supplied the audiovisual backdrop, and determined the content of speeches. Turkey's president was the central figure, and the ritual reflected the spirit and practice of his rule. Crucial for our purposes, the ritual reaffirmed a knowledge repertoire that leaves no space for engagement with the Armenian genocide.

\section{Opposition Rituals: Challenging the Dominant Narrative}

Yet official Turkish knowledge construction is not without challengers among Turks, and these challengers, too, put rituals to use. Egemen Özbek (2016), for example, describes in vivid detail Turkish-Armenian genocide commemorations in Istanbul. Organized by the Human Rights Association (İnsan Hakları Derneği, or IHD) on April 24, 2010, in front of the Haydarpaşa Train Station, a commemorative event attracted some fifty participants. The gathering culminated with Eren Keskin, ${ }^{11}$ a lawyer and human rights activist, reading a press release:

NEVER AGAIN! On April 24, 1915, 220 Armenian intellectuals, who were among the most productive members of the Ottoman artistic, literary and intellectual world, were arrested. First, they were taken to Mehterhane, which was used as central prison, the next day they were taken to Sarayburnu to board on a boat that would take them to the Haydarpasa train station. From there they began their journey towards Anatolia. They were not informed about where they were taken. One group headed to Ayas and the other to Çankiri. 58 of 70 people who were sent to Ayas and 81 of 150 who were sent to Çankiri were killed. Among the killed were leading intellectuals of the time.... Yes, we invite all to be conscientious in line with this convention [Convention for the Prevention and Punishment of the Crime of Genocide] and to properly name the events of 1915 . As human rights defenders we say once again that GENOCIDE IS A CRIME AGAINST HUMANITY and NEVER AGAIN-IHD Istanbul Branch. The Commission Against Racism and Discrimination. (quoted in Özbek 2016:414-415)

The IHD repeated similar ceremonies in 2011, 2012, and 2013. The site was either the train station, symbol of the deportation process, or the front of the building in which the Armenian intellectuals were initially kept after the roundup of April 24, 1915 .

Özbek (2016:419-427) similarly describes the ritual quality of a gathering of hundreds on Taksim Square in Istanbul, organized by an organization named DurDe, a "European Grassroots Antiracist Movement." A banner printed in Turkish, Armenian, and English read, "This is OUR pain. This is a mourning for ALL OF US." The event's emblem, a pomegranate, symbol of Armenian culture-as 
celebrated by Sergei Parajanov's famous film The Color of Pomegranates-but with a deep cut, symbolized the annihilation of the Armenians. Like the IHD, the organizers had chosen a symbol-rich location, across from the Republic Monument memorializing the military victory of the Turkish national struggle and the establishment of the republic under Mustafa Kemal Atatürk's leadership. By 2012, the number of attendees had grown to two thousand, and the event had expanded to other Turkish cities (Özbek 2016:427).

In short, small and courageous groups of Turkish activists and intellectuals challenge the official silencing of the Armenian genocide. They use rituals and powerful symbols to express solidarity with Armenians and to challenge denial. By contrast, the official commemoration of the Conquest of Constantinople establishes a new link to a past regime under which the genocide against the Armenians and mass atrocities against other minorities were committed. The new model, its self-celebratory excess, and its boundary drawing to outgroups (defined as enemies of the people and the sacred nation) do not bode well for a constructive engagement with the genocide.

\section{CONCLUSIONS}

We have seen that rituals are strong mechanisms for the reaffirmation of knowledge repertoires, here knowledge about the Armenian genocide on the side of Armenians, in their own country and in the diaspora, and the evasion of problematic aspects of Ottoman history on the Turkish side. In line with classical (Durkheim [1912] 2001) and modern work (Bellah 1970; Collins 2005; Douglas 1966; Shils 1981), rituals sanctify the nation, strengthen communities, and reaffirm knowledge. Strategic actors, entrepreneurs with substantial resources at hand, initiate and structure these rituals (see also Baer 2011; Karakaya and Baer 2019). They display great epistemic power. In line with Riley's (2008) insights, linking rituals to ancient symbols increases their effectiveness. References to Mount Ararat on the Armenian side and Mehmet the Conqueror on the Turkish side are but examples. The Armenian case further illustrated that we should examine rituals in the spirit of Caplow's (2004) festival cycle (here, a commemoration cycle), where the meaning of one ritual reveals itself fully only in combination with other rituals. Finally, in line with Erikson's ([1966] 2004) insights, rituals play an especially powerful role in times of crisis. They do so particularly when deeply held knowledge repertoires of one group profoundly challenge those of another.

Yet, despite the power of rituals in reaffirming communities and validating knowledge repertoires, challenges from the outside at times provoke direct conflictual engagement with the other, a theme to which the following chapters are dedicated. 